\title{
Captopril-associated cough is not due to increased airway responsiveness
}

\author{
SP BLACKIE MD FRCP, C HILLIAM BSC RCPT, R PORTER BSCN, R RANGNO MSC MD FRCPC, PD PARÉ MD FRCP \\ Divisions of Respiratory Medicine and Clinical Pharmacology, University of British Columbia \\ Pulmonary Research Laboratory, St Paul's Hospital, Vancouver, British Columbia
}

SP Blackie, C Hilliam, R Porter, R Rangno, PD PARÉ. Captopril-associated cough is not due to increased airway reponsiveness. Can Respir J 1994; $1(4): 235-240$.

BACKGROUND: Angiotensin-converting en yne (ACE) inhibitors commonly cause cough. There is controversy ats to whether preexisting airway hyperresponsiveness predisposes patients to ACE inhibitor-induced cough and whether ACE inhibitor therapy can calse airway hyperresponsiveness. OBJectives: To test the predictive value of baseline airway responsiveness for the development of cough induced by ACE inhibitors, and whether patients who developed cough during $\mathrm{ACE}$ inhihitor therapy showed an increase in airway responsiveness.

METHODS: Baseline spirometry and airway responsiveness to methacholine (expressed as the concentration of methacholine required to causc a $10 \%$ fall in forced expired volume in $1 \mathrm{~s}\left[\mathrm{FEV}_{1}\right]$ or $\mathrm{PC}$ (10) were measured in 23 hypertensive patients before and after 10 to 12 weeks of treatment with captopril at an initial daily dose of $50 \mathrm{mg}$.

RESULTS: During captopril therapy seven $(30 \%)$ patients developed new cough, which resolved after discontinuation of captopril. The baseline PC 10 was the same in coughers and noncoughers and did not predict the development of cough. During captopril therapy there was a nomsigniticant decrease in the geometric mean $\mathrm{PC}_{10}$ for all patients from $15 \mathrm{mg} / \mathrm{mL}$ (range 0.8 to 62 ) to $13 \mathrm{mg} / \mathrm{mL}$ (range 0.71062 ) $(\mathrm{P}=0.08)$. These changes were not different in coughers and noncoughers. FEV 1 , forced vital capacity and total lung capacity did not change during the study.

Conclusions: Cough caused by captopril is not predicted by baseline airway responsiveness and is not associated with increased airway responsiveness.

Key Words: Angiotensin-converting enzyme, Asthma, Comsh. Methacholine testing
La toux associée au captopril n'est pas attribuable à une augmentation de la réactivité bronchique

CONTEXTE: Les inhibiturs de l'enıyme de conversion de l'angiotensine provoquent couramment de la toux. Une controverse existe à savoir si une hyperriaclivité bronchiyuc antérieure prédispose les patients à lit foux indute par les inhibiteurs de l'enzyme de conversion de l'angiotensine ou si ces médicaments induisent une hyperréactivité bronchique.

OBJEctrfs: Tester la valcur prédictive de la réalctivité bronchique de base pour le développement de la toux induite par les inhibiteurs de l'enzyme de conversion de l'angiotensine, et vérifier s’il y a une augmentation de la réactivité bronchique chez les patients qui ont développé une toux pendant le traitement avee les inhibiteurs de conversion de l'angiotensine.

MÉTHOdEs : Spirométrie de base et mesure de la réactivité bronchique à la métacholine (exprimée comme la concentration de métacholine nécessaire pour provoquer une chute de $10 \%$ du volume expiratoire forcé en 1 s [VEMS] ou $\mathrm{PC}_{10}$ ) chez 23 patients hypertendus avant et après 10 à 12 semaines do traitement au captopril à une dose initiale de $50 \mathrm{mg} /$ jour.

RÉSUITATS : Pendant le traitement au captopril, 7 patients $(30 \%)$ ont développé une toux qui a cessé après l'arrêt du traitement. La PC 10 de base ćlitit liı même pour les tousseurs et les non-tousseurs et n'avait pas de villeur prédictive pour $\mathrm{l}$ développement de lat toux. Pendant le traitement avec lc captopril, il y avait une diminution non significative dans la moyenne géomćtrique de la $\mathrm{PC}_{10}$ pour tous les patients de $15 \mathrm{mg} / \mathrm{mL}$ (écart 0.8 à 62) à $13 \mathrm{mg} / \mathrm{mL}$. (écart 0,7 à 62) $(\mathrm{P}=0,08)$. Ces changements étaient similaires pour les tousseurs et les non-tousseurs. Le VEMS, la capacité vitale forcée et la capacitć pulmonaire totale sont restées inchangées pendant l'étude.

Conclusions : la toux induite par le Captopril ne peut pas être prédite par la valeur de base de la réictivité bronchique et n'est pas associêc à unc augmentation de la réactivité bronchique.

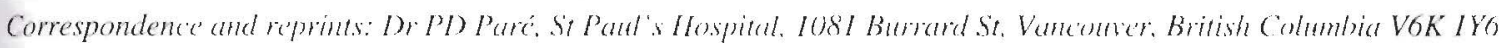


C OUGH ASSOCIATED WITH THE USE OF ANGIOTENSINconverting enzyme (ACE) inhibitors has been recognized since 1985 ( $1-6)$ and this extensive literature has been recently reviewed $(7,8)$. Generally these reports describe cough developing after the commencement of ACE inhibitor therapy and resolving after the drug was discontinued, although symplomatic airway narrowing accompanies the coughing in a small percentage (about $5 \%$ ) of the cases (8). Estimates of the frequency of cough in patients taking $\mathrm{ACE}$ inhibitors range from 0 to $39 \%$ (9-13). The mechanism of the cough and airway obstruction remain uncertain although bronchial hyperresponsiveness, elevated levels of bradykinin or other neuropeptides, alterations in prostaglandin activity and changes in cough threshold have all been proposed as potential factors (7).

Bronchial hyperresponsiveness has been the most extensively investigated potentially predisposing factor, but the results of these studies are conflicting. Dixon et al (14) found no change in the airway responsiveness to histamine or methacholine of asthmatic subjects given a single dose of ACE inhibitor. In another study, only two patients with cough caused by ACE inhibitors had evidence of increased bronchial reactivity (10). However, Bucknall et al (15) observed a small but significant increase in bronchial responsiveness when symptomatic patients were studied during and after discontinuation of $\mathrm{ACE}$ inhibitors and suggested that these patients had increased bronchial responsiveness at baseline. Kaufman et al (16) reported that cough that developed on ACE inhibition seemed to occur in patients with increased airway responsiveness both during and without treatment and called for a prospective study of cough during ACE inhibitor therapy. Ogihara et al (17) reported increased cough in response to citric acid and increased bronchoconstriction in response to histamine in normal volunteers treated with ACE inhibitors. On the other hand Sala et al (18) reported no change in methacholine responsiveness after chronic ACE inhibitor therapy in asthmatic and nonasthmatic subjects. Since severe bronchoconstriction can develop in a subset of patients receiving ACE inhibitor treatment, the ability to predict adverse effects would be advantageous.

We have prospectively studied the airway responsiveness to methacholine of 23 hypertensive patients who were starting therapy with captopril. We focused on the relationship of cough to baseline airway responsiveness as well as the relationship of changes in airway responsiveness during captopril therapy to the development of cough.

\section{PATIENTS AND METHODS}

Patient population: Patients who were taking part in a singleblind crossover study of captopril were asked to participate in the study. Patients gave informed consent before participating in the study which was approved by the ethical review committees of St Paul's Hospital and the University of British Columbia. All previous antihypertensive medications had been stopped at least three weeks before the initial respiratory assessment. No subject was taking captopril or any other ACE inhibitor before being recruited, although three of the subjects had been treated in the past with ACE inhibitors. None of them had a history of cough or any other respiratory disease.

Study protocol: Each subject completed a modified American Thoracic Society questionnaire designed to elicit any history of respiratory or atopic disease. Baseline pulmonary function, including spirometry and lung volumes, were meas ured. Spirometry (forced expired volume in $1 \mathrm{~s}\left[\mathrm{FEV} V_{1} \mid\right.$. forced vital capacity $[\mathrm{FVC}]$ ) was done in a volume displacement, pressure compensated body plethysmograph. Volume was measured using a Krogh spirometer coupled to a linear displacement transducer (Type 300 HR, Shaevitz Engineer ing, New Jersey) and airflow was measured using a Fleisch No 3 pneumotachometer coupled to a pressure transducer (Sanborn 270, Sanborn). Partial and complete maximal expiratory manoeuvres were performed. The partial expiratory flow-volume curves were initiated from end inspiration during tidal breathing and were followed by immediate inhala tion to total lung capacity (TLC) and a complete expiratory flow-volume curve. Flow and volume signals were digitized' and fed to an Apple IIe computer programmed to calculate FEVI and FVC and to display expiratory flow volume loops. After three technically adequate tracings had been obtained, the mean value of the three measurements was calculated and used as the baseline FEV 1 and FVC. Measurements of flow at $50 \%$ and $25 \%$ of measured vital capacity $\left(\dot{V}_{\max } 50, \dot{\nabla}_{\max } 25\right)$ on the complete flow-volume curve were obtained from the digitized flow and volume data as well as flows at an isovolume point between 30 and $35 \%$ TLC on the partial and complete expiratory flow volume curves. Tho racic gas volume was also determined at baseline using Boyle's Law technique followed by an inspiratory capacity manoeuvre to calculate TLC. Mouth pressure was measured using a differential pressure transducer (Validyne $45 \mathrm{MP}$ $\pm 100 \mathrm{~cm} \mathrm{H}_{2} \mathrm{O}$, Validyne Co, California) while the subject was occluded at the mouth and panting at I $\mathrm{Hz}$

After these baseline measurements, patients performed a modification of the inhalation challenge test described by Cockcroft et al (19). Aerosols were generated by a Bennet twin jet nebulizer (Bennett) at an airflow rate of $6 \mathrm{~L} / \mathrm{min}$ Under these conditions, the nebulizer produced an output of $0.13 \mathrm{~mL}$ of aerosol/min with a mean particle size of $3.6 \mu \mathrm{m}$ and a geometric standard deviation of $3.47 \mu \mathrm{m}$. The aerosol was delivered through a three-way stopcock and plastic tubing with a deadspace of approximately $200 \mathrm{~mL}$ while the patient inhaled through the mouth during quiet tidal breathing with the nose closed by a clip. Aerosols were delivered for 2 mins each time. Patients first inhaled an aerosol of isotonic saline followed at 5 min intervals by aerosols of acetyl methylcholine chloride (methacholine) in doubling concentrations from $0.5 \mathrm{mg} / \mathrm{mL}$ to a maximum of $64 \mathrm{mg} / \mathrm{mL}$ The starting dose was lowered to $0.125 \mathrm{mg} / \mathrm{mL}$ if the subjec had a history of atopic rhinitis. Doses were skipped if a fal of less than $3 \%$ in FEV 1 occurred over two successive doses No doses were skipped after the $4 \mathrm{mg} / \mathrm{mL}$ dose was adminis tered. Maximal forced expiratory flows were measured a $30 \mathrm{~s}$ and 2 mins after the completion of each inhalation 
The test was stopped when there was a fall in FEV I of $20 \%$ or more, or when the $64 \mathrm{mg} / \mathrm{mL}$ dose of methacholine had been given.

The percentage fall in FEV, was calculated from the lowest FEV I obtained after the saline aerosol $\left(F E V_{I}-A\right)$ and after methacholine (FEV $-B$ ), as follows:

$$
\frac{100 \times\left(F E V_{1}-A-F E V_{1}-B\right)}{F E V_{1}-A}
$$

If the postsaline FEV , was less than $3 \%$ different from the baseline FEV 1 then the mean of all four efforts was used as FEV 1 -A. The results were expressed as the concentration of methacholine required to provoke a $10 \%$ fall in FEV ( $\mathrm{PC} 10)$, which was calculated by interpolation between the two points on either side of a $10 \%$ fall in FEV . Dose response relationships using maximal flows at 50 and $25 \%$ of $\mathrm{FVC}$ from the complete flow volume curve and flows at the isovolume point on partial and complete curves were also constructed.

The patients were treated with captopril only (initial daily dose $50 \mathrm{mg}$, maximum daily dose $100 \mathrm{mg}$ ) for 12 weeks. The patients had weekly assessments of blood pressure throughout the study. The dose of captopril was adjusted according to the patient's blood pressure. If hypertension was uncontrolled or significant side effects of treatment developed, necessitating withdrawal of captopril, the protocol was immediately terminated (captopril was discontinued at 10 weeks in three patients, one because of poor control and two because of coughing). Just before the end of the 12-week period, patients returned for another assessment. They were questioned at that time regarding the occurrence of any new respiratory symptoms. Spirometry, measurement of lung volumes and inhalation challenge testing were repeated in an identical manner to their first visit.

Cough threshold for inhaled citric acid was also measured in a subgroup of 13 patients (six coughers and seven noncoughers) after completion of the initial protocol. All patients had been withdrawn from captopril therapy for at least one month at the time of the citric acid inhalation test. Cough threshold was determined as previously described by Taylor et al (20). In a single-blind fashion each subject inhaled a control solution of $0.5 \mathrm{M}$ saline followed by increasing concentrations $(0.5,1,2,4,6,8,12,16,24$ and $32 \mathrm{~g} / 100 \mathrm{~mL}$ ) of crystalline citric acid monohydrate (Fisher Scientific, New Jersey) dissolved in $0.5 \mathrm{M}$ saline. Solutions were inhaled every 5 mins from a Puritan Bennett twin jet nebulizer, with subjects carrying out a slow inspiratory capacity manoeuvre wer $5 \mathrm{~s}$. The cough threshold was defined as the lowest concentration of citric acid that consistently elicited an involuntary cough during three separate inhalations.

Data analysis: Data are presented as mean \pm SD or as the geometric mean and range. The anthropometric data of the coughers and noncoughers were compared using a nonpaired thest. Lung function and $\log \mathrm{PC}_{10}$ before and during captopril therapy were compared using a paired $t$ test. The $\mathrm{PC}_{10}$ and cough threshold values of the two groups were compared using the Wilcoxon signed ranks test. $\mathrm{P}<0.05$ was considered
TABLE 1

Data at baseline and on captopril

\begin{tabular}{|c|c|c|}
\hline & Noncoughers $(n=16)$ & Coughers $(n=7)$ \\
\hline Age (years) & $49 \pm 6$ & $54 \pm 5$ \\
\hline Sex (female:male) & $5: 11$ & 6.1 \\
\hline History of atopy & 5 & 3 \\
\hline \multicolumn{3}{|l|}{$\mathrm{FEV}_{1}(\% \text { predicled })^{\dagger}$} \\
\hline Baseline & $107 \pm 7$ & $118 \pm 8$ \\
\hline On captopril & $109 \pm 8$ & $119 \pm 6$ \\
\hline \multicolumn{3}{|l|}{ FVC $(\% \text { predicted })^{\dagger}$} \\
\hline Baseline & $103 \pm 11$ & $105 \pm 9$ \\
\hline On captopril & $105 \pm 12$ & $106 \pm 8$ \\
\hline \multicolumn{3}{|l|}{ TLC $(\% \text { predicted })^{\ddagger}$} \\
\hline Baseline & $103 \pm 11$ & $102 \pm 10$ \\
\hline On captopril & $104 \pm 12$ & $103 \pm 10$ \\
\hline \multicolumn{3}{|l|}{$\mathrm{PC}_{10}(\mathrm{mg} / \mathrm{mL})$} \\
\hline Baseline & $12(0.8-59)$ & $23(9-62)$ \\
\hline On captopril & $11(0.7-57)$ & $18(6-62)$ \\
\hline
\end{tabular}

"The only significant difference between the coughers and noncoughers is the female:male ratio $(P<0.05)$. There were no differences in any of the measurements between the two visits. ${ }^{\dagger}$ Reference 33; ${ }^{7}$ Reference 34. FEV 1 Forced expired volume in $1 \mathrm{~s} ;$ FVC Forced vital capacity; TLC Total lung capacity; $P C_{10}$ The concentration of methacholine required to cause a $10 \%$ fall in FEV $V_{1}$. All values except $P C_{10}$ are expressed as mean $\pm S D$. $P C_{10}$ is expressed as the geometric mean and the numbers within brackets represent the range

significant. All calculations, including power analysis, were done using Systat (Illinois).

\section{RESULTS}

Results from the 23 patients who completed the study are summarized in Table I. Seven (30\%) patients complained of new cough during captopril therapy that resolved when captopril was discontinued. Only one subject was an active smoker and he did not develop a cough. A much higher incidence of cough occurred among females ( $s i x$ of $11,55 \%$ ) versus males (one of $12,8 \%$ ), $\mathrm{P}<0.05$. The percentage of subjects who gave a history consistent with atopic rhinitis was similar between coughers and noncoughers. Baseline FEV , FVC, $V_{\max } 50, \dot{V}_{\max } 25$ and TLC were normal in both groups. None of these measurements were different during therapy.

Figure I shows both sets of measurements of $\mathrm{PC}_{\mathrm{I}}$ for the two groups. The baseline geometric mean $\mathrm{PC}_{10}$ for the 23 subjects was $15 \mathrm{mg} / \mathrm{mL}$ (range 0.8 to $62 \mathrm{mg} / \mathrm{mL}$ ) and after treatment with captopril was $13 \mathrm{mg} / \mathrm{mL}$ (range 0.7 to 62 $\mathrm{mg} / \mathrm{mL})(\mathrm{P}<0.08)$. There was no difference between the baseline $\mathrm{PC}_{10}$ of the coughers and noncoughers; there was no difference in the changes in bronchial responsiveness between the coughers and noncoughers.

There was no difference in the shape or position of the dose response curves constructed using methacholine concentration and partial or complete maximal flows at low lung volumes between coughers and noncoughers or in coughers before and after captopril therapy. Thirteen patients (seven noncoughers, six coughers) completed the citric acid inhalation test. As shown in Figure 2, the geometric mean cough 


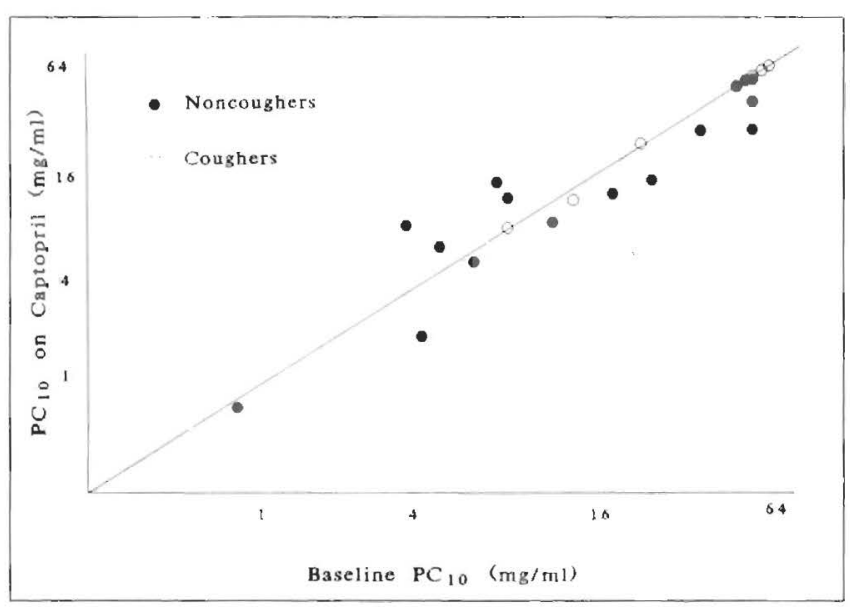

Figure 1) Each sambol represents the values for. $P C_{10}$ (the concentration of methacholine required us curse a $10 \%$ fall in forced expired bolume in / s) ohnainced in a single patient at two visits. There is no difference between the two visits. The solid line is the line of identity

threshold was not different in the two groups, ic. $7.4 \mathrm{~g}$ citric acid/100 $\mathrm{ml}$. (range 3108 ) in the noncoughers and $9.2 \mathrm{~g}$ citric acid/lo() $\mathrm{mL}$ (range $5 \mathrm{to} 17$ ) in the coughers.

\section{DISCUSSION}

The results of this study demonstrate that ciptopril-induced cough is not predicted by increased baseline arrway responsiveness. The data also show that captopril-induced cough is not associated with an increase in airwaly responsiveness during 12 weeks of treatment. We found a high incidence of captopril-induced cough $(30 \%)$ with a marked preponderance in women.

The cough reported in atssociation with ACE inhibitors is unique :mong respiratory side effects of drugs. The lung is a common site for drug-related side effects (21), but cough apparently without chatnges in the lung parenchyma or airway obstruction is not associated with other classes of drugs. ACE inhibitors have been implicalled in the worsening of asthmatic symptoms $(8,22,23)$ and in parenchymal lung disease (24), but these reports are rare compared with the number of reports on the occurrence of isolated cough. The mechanism of the cough remains unknown. We chose to study the relationship of cough induced by ACE inhibitors to airway hyperresponsiveness because of the implications of this potential relationship on the treatment of hypertension and/or congestive heart failure in asthmatic patients.

We used $\mathrm{PC}_{10}$ as the marker of airway responsiveness rather than the more commonly used $\mathrm{PC}_{20}$ in order to obtain a measured value for bronchial responsiveness in a larger percentage of patients. We expected to be able to measure $\mathrm{PC}_{20}$ in no more than $20 \%$ of patients without a previous diagnosis of asthma or other respiratory disease; this may have prevented interpretation of the results in a large number of subjects and excluded patients with normal bronchial responsiveness. $\mathrm{PC}_{10}$ is a convenient method of expressing the responsiveness of the airways, although it may not have the same implications for clinical disease as does $\mathrm{PC}_{20}$. The

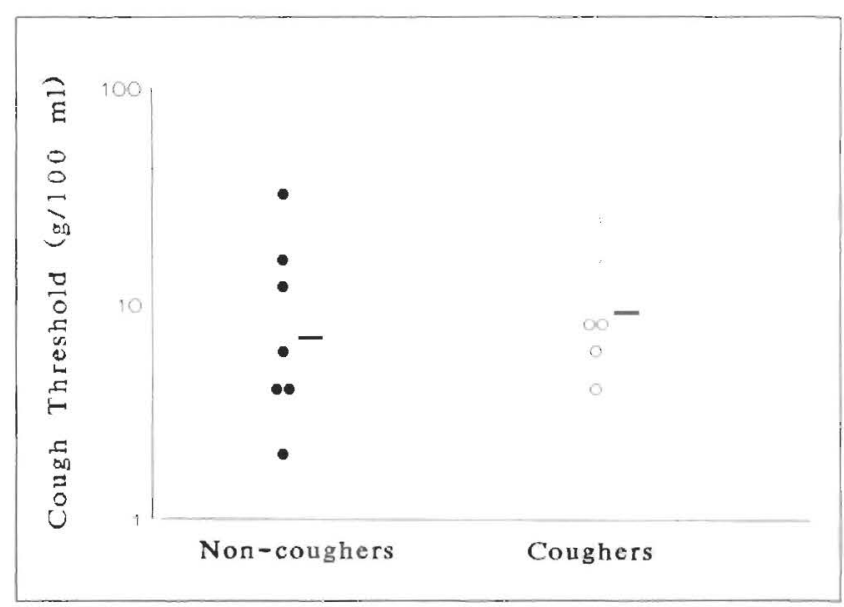

Figure 2) There is no difference in the geometric mean cough threshold of the coughers and noncoughers. The solid horizontal bars represent the geometric mean cough thresholds of the two groups.

separation of coughers and noncoughers and the detection of changes in responsiveness in coughers was not improved by using flows low in the vital capacity or from partial flow volume curves.

The incidence of cough $(30 \%)$ we observed is at the upper end of the range previously reported $(7,25,26)$. One possible explanation for this is that we were specifically asking about the occurrence of cough, and the patients were aware that cough was a potential side effect of captopril. In addition, a relatively high proportion of our patients was female, a group of patients previously demonstrated to have a higher incidence of ACE inhibitor-induced cough (26,27). Our findings support these earlier reports. Finally, not all patients who report cough initially while on ACE inhibitor therapy report cough again when rechallenged with the drug (10).

Results from previous studies of ACE inhibitors, in which investigators measured airway responsiveness, are conflicting. The results of two studies $(15,16)$ showed increased airway responsiveness in patients who had a history of ACE inhibitor-induced cough but were no longer taking ACE inhibitors. One of these studies reported a small but significant increase in airway responsiveness when their patients were rechallenged with ACE inhibitors (15), while the other study did not show consistent changes (16). Both studies were retrospective investigations of patients previously identified as susceptible to ACE inhibitor-induced cough. A third retrospective study (28) demonstrated increased histamine responsiveness during treatment with enalapril which was not present in a placebo-treated group. This study lacked a control group of noncoughers. In a study of normal volunteers, Ogihara et al (17) reported increased cough in response to citric acid and increased bronchoconstriction in response to histamine following captopril or enalapril therapy.

In contrast, other studies have reported no effect of ACE inhibitors on airway responsiveness. A single dose of ramipril did not alter the airway responsiveness of asthmatic subjects (14). Sala et al (I8) reported no change in 
methacholine responsiveness after chronic captopril treatment in 16 hypertensive asthmatic subjects and 15 hypertensive nonasthmatics. In another study, only two of seven patients with ACE inhibitor-induced cough had increased airway responsiveness at baseline and no changes in airwaty responsiveness were observed during therapy (10). Boulet et al (29) reported no significant change in lung function or airway responsiveness during eight weeks of treatment with captopril in 15 patients, four of whom developed cough. However, there was a trend towards increased responsiveness in patients on captopril, and this study may have been weakened by the inability to yuantify the degree of airway responsiveness (as judged by $P_{2(1)}$ ) at either visit in six of their 15 subjects. These authors raised the possibility that more sensitive tests of airway responsiveness might detect changes that their study had missed. Our results, using flows at low lung volumes and before at deep inhalation, do not support this hypothesis.

We did not find a significant change in the airway responsiveness of our patients treated with captopril for 12 wecks. We considered that a change of one doubling dose in the arway responsiveness of our patients would be clinically significant. The power of our study to exclude such a differtnce in the entire patient group ( $\mathrm{n}=23$ ) exceeds $95 \%$ and in our group of coughers ( $n=7$ ) exceeds $90 \%$. It is possible that a small change in airway responsiveness occurs during therapy with ACE inhibitors. Previous reports in the literature $(15,17,28,29)$ have suggested this possibility, and the change seen in this study approached but did not reach statistical significance $(\mathrm{P}=0.08)$. Such a small change in airway responsiveness is unlikely to be clinically important.

Furthermore, it is clear from our lindings that there is no relationship between the development of cough and increased bronchial responsiveness, either at baseline or during 12 weeks therapy with captopril. Figure 1 demonstrates the range of $\mathrm{PC}_{10}$ values measured. Clearly the range of $\mathrm{PC}_{10}$

ACKNOWLEDGEMENTS: Supported by the Medical Research Council of Canada. Dr Blackie was a Fellow of the Canadian Lung Association. Dr Rangno was supported by the BC Heart Foundation

\section{REFERENCES}

1. Sesoko S, Kaneko Y. Cough associated with the use of captopril. Arch Intern Med 1985;145:1524.

2. Nash DT. Lisinopril cough. Postgrad Med 1980;80:40).

3. Webb D, Benjamin N, Collicr J, Robinson B. Enalitpril-induced cough. Lancet 1986;ii: 1094.

4. Carruthers SG. Severe coughing during ciuptoptil and enalipril therapy. Can Med Assoc J 1986:135:217-8.

5. Hood S, Nichols MG, Gilchrist JL. Cough with angiotensin converting-enzyme inhibitors. NZ Med J 1987;100:6-7.

6. MeNally EM. Cough duc to captopril. West J Med 1987;146:226-8.

7. Iraili ZH, Dallas Hall W. Cougl and angioneurotic edema associated with angiolensin-converting enzyme inhibitor therapy. Ann Intern Med 1992;117:234-42.

3. Lunde H, Hedner T, Samuelsson O, et al. Dyspnocat. asthula, and bronchospasm in relation to treatment with angiotensin converting enzyme inhibitors. BMJ 1994;308:18-21.

Rumboldt 7. Marinkovic M, Drinovec J. Enalapril versus values of the coughers is not lower than that of the noncoughers. Measurement of a patient's methacholine responsiveness before receiving therapy with captopril would not help a clinician to predict the development of cough. Because captopril treatment did not increase nonspecific airway responsiveness, these data suggest that symptoms of asthma should not worsen during captopril therapy. However, asthmatic symptoms do develop in a small proportion of patients who receive $\mathrm{ACE}$ inhibitor therapy, and preexisting airway disease is a predictor of these rare adverse responses (8).

Previous studies have examined the relationship between cough threshold and ACE inhibitor-induced cough. Fuller and Choudry (30) demonstrated an increased cough response 10 capsaicin inhalation in five patients who had developed ACE inhibitor-induced cough. Testing after stopping the drug showed that the cough sensitivity had returned to normal levels. The results of a subsequent study from this group (31) showed that baseline sensitivity to capsaicin is normal in patients who develop cough while taking ACE inhibitors. Morice et al (32) also showed that captopril significantly shifts the cough dose response curve to capsaicin inhalation in normal subjects. In this study, there was no change in cough frequency after inhalation of citric acid, but dose response curves for neither citric acid nor thresholds for cough were assessed. From our small study population $(n=13)$ it appears that cilric acid sensitivity is not different in coughers from noncoughers. Whether there is any change in cough threshold to citric acid during ACE inhibitor therapy is unknown.

\section{CONCLUSIONS}

This prospective study showed that baseline airway responsiveness does not predict the development of captoprilinduced cough. As well, captopril-induced cough is not alssoc liated with an increase in airwaly responsiveness. Cough is a common side elfect of ACE inhibitors and women are at increased risk of this complication.

captopril: a double-blind multicentre comparison in essential hypertension. Int J Clin Pharmacol Res 1988;8:181-8.

I0. Town GI, Hallwright GP, Maling TJB, O'Donnell TV. Angiotensin converting enzyme inhibitors and cough. NZ Mied J 1987;100:161-3.

11. Just PM. The positive association of cough with angiotensin-converting enzymc inhibitors. Pharmacotherapy 1989;9:82-7.

12. Goldszer RC. Lilly I.S, Solomon HS. Prevalence of cough during angiotensin-converting enzyme inhibitor therapy. Am J Med 1988;85:887.

13. Lacourcière Y, Poirier L, Provencher P, Guivarch PH. Once vs twice daily administration of a fixed combination of Laptopril plus hydrochlorothiazide in essential hypertension: a double-blind crossover study in known responders 10 al standard combination. Br J Clin Pharmacol 1991:32: I 15-4.

14. Dixon CS, Fuller RW, Barnes PJ. The effect of an angiotensin converting enzyme inhibitor, ramipril, on bronchial responses to inhaled histamine and bradykinin in asthmatic subjects. Br J Clin Pharmacol 1987:23:91-3.

15. Bucknall CE, Neilly JB, Carter R, Stevenson RD, Semple PF. Bronchial hyperreactivity in patients who cough after receiving angiotensin converting enzyme inhibitors. BM J 1988;296:86-8.

16. Kaufman J, Casanova JE, Riendl P, Schleuter DP. Bronchial 
hyperreactivity and cough due to angiotensin-converting inhibitors. Chest 1989;95:544-8.

17. Ogihara T, Mikami H, Katahira K, Otsuka A. Comparative study of the effects of three angiotensin converting enzyme inhibitors on the cough reflex. Am J Hypertens 199 I;4:46s-5Is.

18. Sala H, Abad J, Juanmiquel LI, et al. Captopril and bronchial reactivity. Post Grad Med J 1986;62(Suppl 1):76-7.

19. Cockcroft DW, Killian DN, Melon JJA, Hargreave FE. Bronchial reactivity to inhaled histamine: a method and clinical survey. Thorax 1988;43:65-70.

20. Taylor I)R, Reid WD, Paré PD, Fleetham JA. Cigarette smoke inhalation patterns and bronchial reictivity. Thorax 1988:43:65-70.

21. Rosenow EC III. Drug-induced pulmonary disease. In: Murray JF, Nadel JA, eds. Textbook of Respiratory Medicine. Philadelphia: WB Saunders Co, 1988.

22. Semple PF, Herd GW. Cough and sneeze caused by inhibitors of angiotensin-converting enzyme. N Engl J Med 1986;314:6]

23. Popa V. Captopril-related (and-induced?) asthma. Am Rev Respir Dis 1987;136:999-1000.

24. Schatz PL, Mesologites D, Hyun J, Walker Smith GJ, Lahiri B. Captopril-induced hypersensitivity lung disease: an immune-complex-mediated phenomenon. Chest 1989;95;685-7.

25. Berkin KE, Ball SG. Cough and angiotensin converting enzyme inhibition. BMJ 1988:296:1279. (Edit)

26. Gibson GR. Enalapril-induced cough. Arch Intern Med
1989; 149:2701-3.

27. Coutter DM, Edwards IR. Cough associated with captopril anm? enalapril. BMJ 1987;294:1521-3.

28. Lindgren BR, Rosenqvist U, Ekström, Grönneberg R. Karlberg BE, Andersson RGG. Increased bronchial reactivity and potentiated skin responses in hypertensive subjects suffering from coughs during ACE-inhibitor therapy. Chest 1989:95:1225-30.

29. Boulet LP, Milot J, Lampron N, Lacourcière Y. Pulmonary function and airway responsiveness during long-term therapy with captopril. JAMA 1989;261:413-6.

30. Fuller RW, Choudry NB. Increased cough reflex associated with angiotensin converting enzyme-inhibitor cough. BMJ 1987:295: 1025-6.

31. McEwan JR, Choudry N, Street R, Fuller RW. Change in cough reflex after treatment with enalapril and ramipril. BMJ 1989;299:13-6

3.. Morice AH, Lowry R, Brown MJ, Higgenbottam T. Angiotensin-converting enzyme and the cough reflex. Lancet 1987;ii:1116-8.

33. Crapo RO, Morris AH, Gardner RM. Reference spirometric values using techniques and equipment that meet ATS recommendations. Am Rev Respir Dis 1981:123;413-6

34. Goldman MI, Becklake MR. Respiratory function tests normal values at medium altitude and predictions of nom results. Am Rev Respir Dis 1959;76:457-67. 


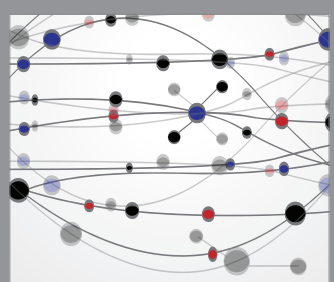

The Scientific World Journal
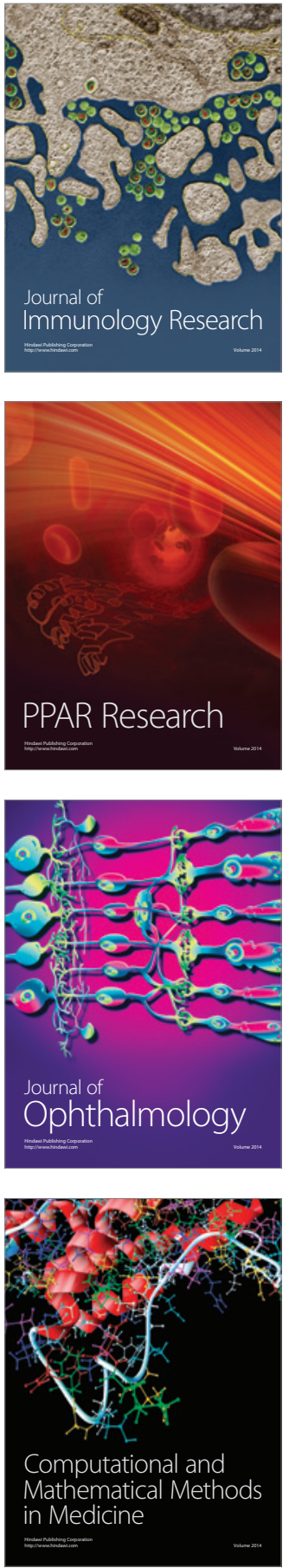

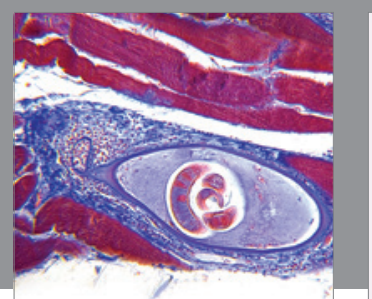

Gastroenterology Research and Practice

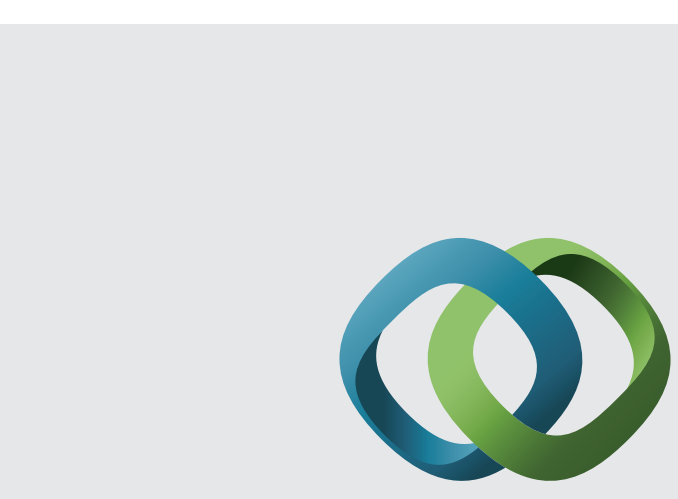

\section{Hindawi}

Submit your manuscripts at

http://www.hindawi.com
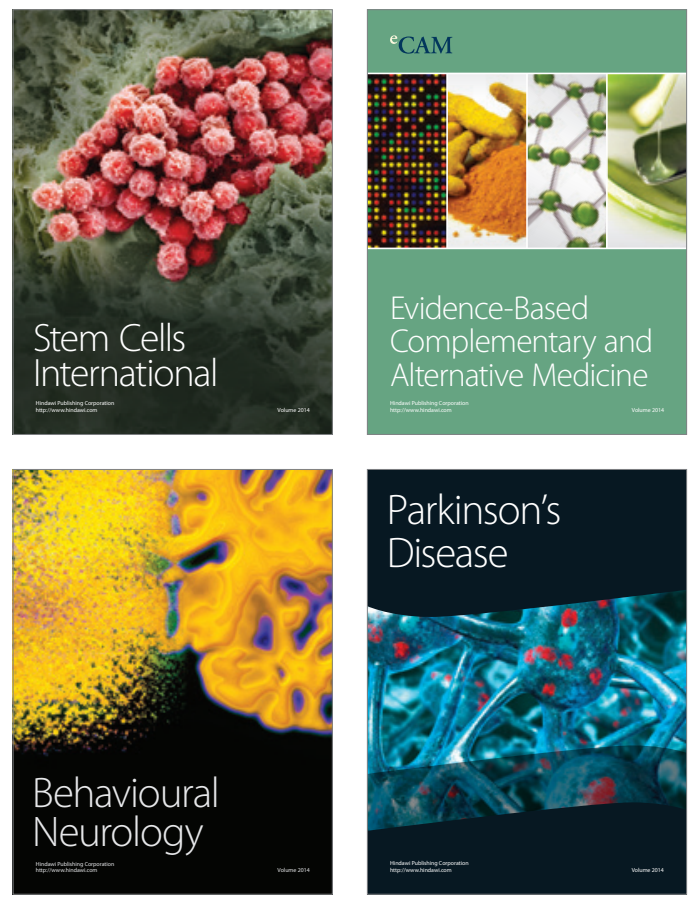
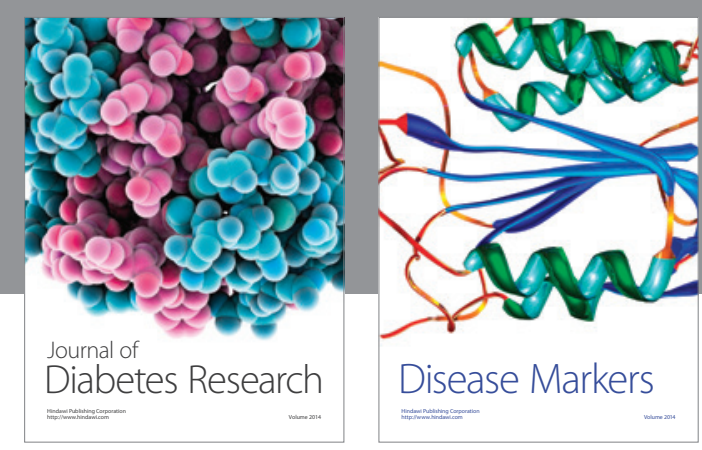

Disease Markers
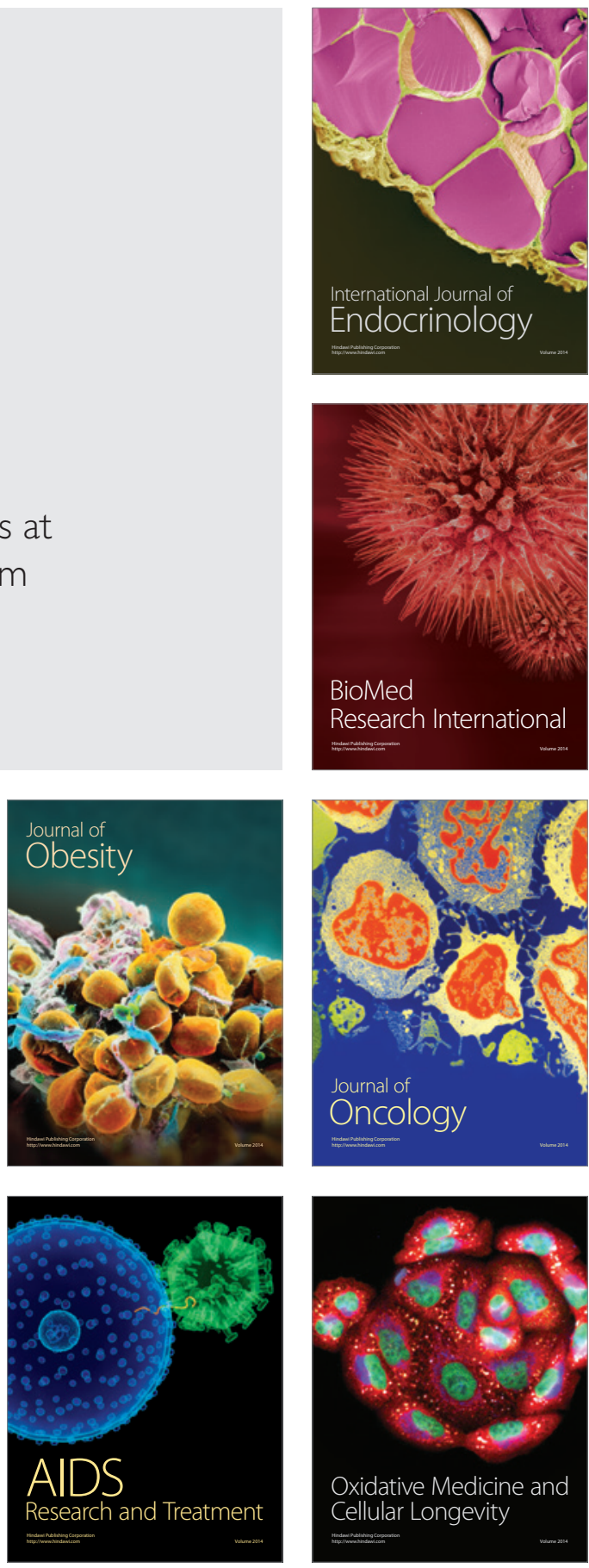